This is the version of the article accepted for publication in New Political Economy, 19 (6). pp. 791-818, published by Taylor and Francis. https://doi.org/10.1080/13563467.2013.849674

Re-use is subject to the publisher's terms and conditions

Accepted version downloaded from SOAS Research Online: http://eprints.soas.ac.uk/36244

\title{
The Political Economy of Energy Transitions: The Case of South Africa ${ }^{1}$
}

Lucy Baker (University of Sussex), Peter Newell (University of Sussex) \& Jon Phillips (King’s College London)

Post-print version. For the publisher's version see: http://dx.doi.org/10.1080/13563467.2013.849674

\begin{abstract}
This paper explores the political economy of energy transition in South Africa. An economic model based around a powerful 'minerals-energy complex' that has previously been able to provide domestic and foreign capital with cheap and plentiful coal-generated electricity is no longer economically or environmentally sustainable. The paper analyses the struggle over competing energy visions, infrastructures and political agendas in order to generate insights into the governance and financing of clean energy transitions in South Africa. It provides both a rich empirical account of key policy developments aimed at enabling such a transition and provides reflections on how best to theorise the contested politics of energy transitions.
\end{abstract}

Key words: energy politics, transitions, South Africa, governance, climate change

Introduction: From global pariah to rising power: South Africa in an era of globalisation

At the Copenhagen climate change summit in December 2009 President Jacob Zuma pledged to reduce the country's greenhouse gas emissions by 34 per cent by 2020 and 44 per cent by 2025 , which he claimed was consistent with its Long Term Mitigation Scenarios endorsed by Cabinet in 2008 (DEAT 2007). Yet even as this pledge target was being agreed, South Africa was facing a crisis of electricity generation which resulted in rolling blackouts and mine closures across the country in 2008 with threats of further black outs beyond 2012. Narrow margins between the supply and demand of 
electricity has led the country's monopolistic utility Eskom to enter into costly buyback agreements in which high-intensity industrial energy users are paid not to use electricity by scaling-down production. Since 2005 Eskom, which currently generates 95 per cent of its electricity, has been struggling to build an additional 17,000 MW of generation capacity by 2018 whilst facing a funding crisis that has led to maintenance backlogs and delays (Eskom 2011:61). In April 2010 the national energy regulator (NERSA) approved three year-on-year tariff increases of 25 per cent between 2010 and 2013, while in March 2013 NERSA agreed further increases of an average 8 per cent per year up to 2018, following requests by Eskom for an increase of 16 per cent. This will see electricity prices rise to $65.51 \mathrm{c}$ a kilowatt-hour $(\mathrm{kWh})$ in the $2013 / 14$ financial year and $89.13 \mathrm{c} / \mathrm{kWh}$ in. By 2020 they could be as high as an average of 110c/kWh (Creamer Media 2011:12). The era of cheap electricity, of particular benefit to the country's large energy intensive users, is over.

Until the supply crises in 2008 the country had the cheapest electricity prices in the world at average R0.25 cents per kWh (\$USD 0.027) (Edkins et al 2010:14). Indeed, the material base of South Africa's minerals-energy complex (Fine and Rustomjee 1996) is an economy structurally dependent upon energy intensive growth, driven by mining and minerals beneficiation ${ }^{2}$, and reliance on abundant sources of low cost coal for 96 per cent of its electricity. However, the dependence by industry on cheap coal for electricity generation is no longer sustainable. In 2009 a 2c/kWh levy was introduced on electricity generated from non-renewable sources. South Africa is the largest source of greenhouse gas emissions in Africa and, in contrast to other developing countries with relatively low GDP and high rates of poverty, the country's per capita emissions are high, comparable even to many EU countries including the UK and Germany and four to five times higher than Brazil or India. Its electricity utility Eskom is the country's and the continent's largest greenhouse gas emitter (CDP 2011). Meanwhile, the country's Energy Intensive User's Group (EIUG), whose 36 members include some of the world's largest resource and mining conglomerates that also hold a monopoly over the country's coal production, consumes around 44 per cent of the country's electricity and represents the largest emitters of greenhouse gases. These companies include BHP Billiton, Anglo-American, Xtrata and the coal-to-liquid fuels pioneer Sasol. 
As will be explored further below, South Africa's energy sector is characterised by its unique social, political and economic legacy of apartheid which continues to impact the contemporary politics of energy transition in profound ways. Before the end of apartheid in 1993 only 36 per cent of the population were connected to the electric grid, with inequality of access defined by race (CURES 2009). While Eskom's unprecedented expansion programme between 1994 and 2000 saw 2.4 million houses connected to the grid (McDonald 2009:15) one third of the country's population are still without access to electricity, particularly in rural areas. Millions of low-income houses do not have enough regular income to buy electricity, even if they are grid connected and account for no more than 5 per cent of national electricity consumption (McDonald 2009:16). Another legacy of apartheid has been South Africa's 'special purchasing agreements' - long term agreements with energy intensive users conceived as a response to sanctions against foreign investors in the apartheid regime. It was not until 2010 that some of these were renegotiated (Carnie 2010), with others due to expire in the next few years.

A series of processes are now converging to force the issue of the sustainability of South Africa's energy path. Yet unlike the orderly and managed processes of change anticipated in some of the literature on socio-technical transitions that we describe below, South Africa is to some extent already undergoing a transition from an era of 'energy opulence' to one of restraint imposed by a series of infrastructural, economic, environmental and physical constraints. Meeting these challenges will involve difficult trade-offs about how to manage conflicting pressures in a way which protects jobs, assists socio-economic development and addresses the economic disadvantage of the historically marginalised population. The production of energy has to enhance the employment prospects of the 25 per cent of the population that remain unemployed while also addressing the issue of energy poverty. In this regard there has been a discursive embrace of rhetoric about the 'green economy' to address unemployment through clean and renewable energy, particularly the creation of low skilled jobs. This is now prominent in a number of government documents emanating from the Department of Trade and Industry and the Department of Energy which we return to further below. ${ }^{3}$ NGOs such as Earthlife, as part of their 'Renewable Energy is Peoples' Energy' campaign, also paint a positive 
picture of direct jobs per unit of electricity (for every 10 gigawatt/hours of energy generated) in which current coal provides 3 , future coal could provide 7 but where solar panels create 620 jobs and wind 126 per unit of electricity generated (EarthLife 2013). Meanwhile, the Energy Intensive Users Group (EIUG) which has "enormous collective bargaining power" (Nakhooda 2011:21) and Business Unity South Africa (BUSA) view moves to check the growth in carbon emissions such as a proposed carbon tax with great suspicion and have questioned the viability of the country's emissions reduction target. Nevertheless, some sectors of the business community in South Africa have sought to lever carbon finance through hosting carbon offset projects. South Africa is one of the few countries in subSaharan-Africa to have projects registered under the Kyoto Protocol's Clean Development Mechanism (CDM) even if, as we will see below, the CDM has not gained significant traction in South Africa and tends to be viewed merely as an additional funding stream rather than a game changer in energy policy deliberations.

There have been some notable policy developments at the national level, nevertheless, that have brought into being coalitions of actors that are positioning themselves to benefit from the introduction of renewable energy, despite on-going resistance from the incumbent regime of existing actors. These include the Renewable Energy Independent Power Producers Programme (RE IPPPP) and the Integrated Resource Plan for electricity (IRP 2010), discussed further below. Unsurprisingly these moves have not been made without significant political negotiation and conflict within and beyond government. At a policy level these contests have played out around the Long Term Mitigation Scenarios (LTMS) for the country and over the desirability or otherwise of carbon trading schemes over the Treasury's stated preference for a taxation scheme in which they would exercise greatest control over the revenues it generates. The first purpose of this paper then is to provide an empirical analysis of three initiatives: RE IPPPP, IRP and CDM to explore the extent to which they might bring about change in South Africa's energy governance. The second is to use these cases to explore the political economy of transitions and thereby engage with a growing literature on that theme that we now introduce. 


\section{Thinking about Transitions}

So how are we to make sense of the dilemmas and challenges that South Africa faces as it negotiates the terms of a move away from an entirely fossil fuel dependent economy? Recent years have seen growing international policy interest in low carbon energy transitions. The term provides both a description of a process of transformation from one energy system to another as well as a set of tools and concepts, to explain and enable such transitions. There already exists a large body of academic work on socio-technical transitions which seeks to understand how, when and where transitions to low-carbon socio-technical regimes can come about (Rip and Kemp 1998, Meadowcroft 2005, 2011; Geels and Schot 2007; Scrase and Smith 2009).

The term 'socio-technical transitions' refers to 'deep structural changes' in systems such as energy and transport, which involve long-term and complex reconfigurations of technology, policy, infrastructure, scientific knowledge, and social and cultural practises to sustainable ends (Geels 2011:24). The wide-ranging transitions literature originally draws from institutional theory, evolutionary economics and the sociology of technology (Rip and Kemp 1998, Geels and Schot 2007) and more recently from political science and theories of governance (Kern 2011; Meadowcroft 2011; Verbong and Lorbach 2012). Contemporary work on socio-technical transitions exists under a variety of permutations, of which the most relevant for this research is the multi-level perspective (MLP) (Rip and Kemp 1998; Geels 2002, 2011). This analyses systems change from the level of 'landscapes', 'regimes', and 'niches' as illustrated in figure 1 and is useful here because it attempts to capture the way in which technological and political change is embedded within and affected by broader global processes such as is the case with South Africa.

A regime refers to patterns of technologically determined behaviour which is shaped by 'cognitive routines' shared by engineers and influenced by policy makers, scientists, energy users, vested interests and other professional groups (Geels and Schot 2007:400). Though gradually evolving, events and structures within the regime are stable and fairly predictable, and protected by 'lock-in' mechanisms (Unruh 2000). In the context of our case study the regime level incorporates the state- 
run, coal-generated, publicly-funded electricity sector and related institutions, policies and structures at the national level. A niche, meanwhile, refers to a protected space at the micro-level, where 'radical innovations' (Geels 2011:27) and learning such as new technologies, markets, ideas, practices and policies emerge which deviate from the dominant regime (Lehtonen and Kern 2009). These are carried out by 'small networks of dedicated actors, often outsiders' and are unstable in nature (Geels and Schot 2007:400). In South Africa this applies to the emerging entrepreneurial cluster of renewable energy independent power producers backed by bi-lateral donors and private finance, some of whom seek to gain carbon finance through the CDM.

A 'landscape' meanwhile refers to the external environment or influences at the macro-level. Geels (2011:28) argues that it includes 'demographical trends, political ideologies, societal values and macro-economic patterns' and influences dynamics at the levels of the regime and the niche. These form the deep structural relationships of a society and change only slowly (Foxon et al 2010: 1204). We define this empirically to include international trends and costs in renewable energy technologies, the role of development finance institutions such as the World Bank and market-based policy instruments such as the CDM. Our emphasis here is on understanding the role of international factors' in order to identify the ways in which domestic policy choices and debates are shaped, enabled and constrained by 'external' macro-economic forces and political actors, institutions and processes, or what might also be characterised as 'governance from above' (Newell et al 2009). This broader landscape of energy politics clearly has the potential to alter the balance of power within South Africa between entrenched coal-based interests at the regime level and emerging niches in renewable electricity generation since both of these levels interact with and are backed by stakeholders and events at the 'landscape' level (Baker 2012). The appeal of the MLP is its ability to provide a 'useful theoretical idiom to explore change processes' and an 'impressive set of historical studies of system transitions' (Geels 2005 and Geels and Schot 2007 quoted in Meadowcroft 2011:21). As a framework the MLP is concerned with the way in which incumbent regimes lose stability and thereby undergo transitions as a result of coordinated pressures from the niche and landscape levels (Byrne et al 2011:57). Such a perspective has the potential to provide a multi- 
dimensional analysis of the dynamics of structural change (Geels 2011) and the complex and often competing interaction between numerous different technologies, actors, institutions, networks and processes, all of which operate within the socio-technical system (Lawhon and Murphy 2011). It offers, therefore, a valuable starting point for making sense of the multi-scalar developments taking place in South Africa's energy sector.

Meanwhile, a 'transition management' (TM) approach, such as that advocated by Kemp et al. (2007), is said to offer 'a practical toolbox of techniques to encourage collaboration among innovators' (Meadowcroft 2011:71). TM uses analytical insights from the literature on socio-technical regimes to bring about gradual low carbon transitions in unsustainable regimes by 'steering evolutionary dynamics towards specific visions' through a consensus-based approach (Scrase and Smith 2009:708). This involves negotiation with non-state and social actors from beyond the regime (Smith et al 2005:1502).

The TM approach has provoked a number of criticisms, nevertheless. First, while a combination of agency, uncertainty and complexity are thought to facilitate policy steering, TM approaches place significant emphasis on the ability of 'bottom up' niche lead innovations to bring about change, but often fail to adequately consider powerful landscape or regime stakeholders with broad and complex international linkages such as multinational firms, whose behaviour cannot be easily shaped by the state (Meadowcroft 2005:487-491). Here the sorts of political economy approaches that we introduce below provide a useful complement by highlighting the nature of resistance to change and the forms of power brought to bear to this end. Second, much of this literature derives from the experience of OECD and European countries, yet there is pressing need to understand the potential nature of emergent transitions in rapidly industrialising countries whose carbon emissions are among the world's highest (China) or whose economies are among the most energy-intensive in the world (such as South Africa's). This raises the question as to whether and how well the TM literature travels to other contexts. Besides work on technology innovation and transfer in India and China (e.g Das 2011; Wang and Watson 2010), work on energy transitions in sub-Saharan Africa appears to be limited 
(Prasad 2008). There are questions about the relevance of this literature for South Africa, therefore. Assumptions which might not translate include: a population with universal access to electricity, conditions of electricity liberalisation (whereas South Africa has a monopoly provider), assumptions about the rational and managed nature of change (rather than responding to crises such as outages and an outdated grid); as well as about the nature of state-market relations. This paper makes a contribution to understanding whether such ideas usefully illuminate the politics of South Africa's current efforts to manage the complex politics of energy transition by providing an original empirical analysis of a series of key initiatives at the level of niche, regime and landscape.

\section{Figure 1 here}

\section{From Policy to Politics and Political Economy}

A further, more conceptual, contribution of our paper is to improve our understanding of the politics and political economy of socio-technical (energy) transitions. In this sense our paper responds to calls from others who find the 'political economy of energy transitions is a vastly understudied area' (Goldthau and Sovacool 2012:238). While a number of transitions writers assert that politics is important in the transitions approach, it is largely missing from much of the existing analysis (Lehtonen and Kern 2009, Smith and Stirling 2007, and Meadowcroft 2009, 2011). Instead, a more narrow focus on policy management characterises much of the literature reflecting a 'tendency toward techno-economic determinism' amongst practitioners of the approach (Lawhon and Murphy 2011:6). This explains Meadowcroft's call to political scientists 'to develop a politically oriented literature on sustainability transitions equivalent in sophistication to that produced by our innovation-oriented colleagues' (2011:70) because 'behind policy there is always politics' (2011:73).

In order to draw out more explicitly the politics of transitions we bring a critical political economy analysis to bear which others have noted is also relatively absent from analysis of the power sector in post-apartheid South Africa (Büscher 2009). Fine and Rustomjee note, for example, that "in the 
transition from apartheid to post-apartheid an historically aware analysis of "the social forces of production" in the context of South Africa's political economy has been abandoned for "technical solutions to the economics of transition' (Fine and Rustomjee 1996:4). To correct this we make use of the literature on the 'minerals-energy complex' (MEC) (Fine and Rustomjee 1996). The MEC provides both a description of the relationship between South Africa's minerals and energy sectors, as well a framework of analysis for the country's political economy. The MEC is a regime of accumulation based on low cost state-owned electricity production (via Eskom) and cheap labour, the incorporation of Afrikaner political power into the mining sector under apartheid and the rationalisation of finance houses, since converted into large-scale national and international corporate capital, tightly bound to energy and mining capital (Swilling and Annecke 2012: 218).

It is more than just a vested interest like any other, therefore. In particular, it helps to understand power relations built upon an historical dependence on abundant coal resources and exploited labour based on racial divisions for the generation of cheap electricity for minerals-based export-oriented industry (Makgetla and Seidman 1980). As Freund (2010) claims, the MEC continues to offer 'a way of understanding power and key networks in South Africa's political economy', an 'architecture' which encompasses critical links between the financial sector, parastatals, government, the private sector and the International Development Corporation, while Tyler and Winkler suggest the MEC 'is so central to the economy that it is likely to take decades to change dramatically' (Tyler and Winkler 2009:3).

Though the essential nature of the minerals-energy complex still stands, in the post- apartheid era a number of changes have taken place within it. These include the formation of new black elites through corporate incorporation, reassignment of mineral rights and public procurement and high level office. A second major evolution is the "financialisation" of the country's resource conglomerates, the transfer of primary listings from the JSE to overseas stock exchanges such as London (Fine 2008:3) and the liberalisation of capital flows into and out of the country. The latter has resulted in increasing levels of capital flight and disinvestment and the often illegal expatriation of domestic capital by large 
conglomerates that could otherwise have been used for national development. Other aspects endure, but have brought with them new challenges. Cheap labour based on racial divisions and the country's century old migrant labour system as a central input into South Africa's minerals-energy complex still persists, but also creates a crisis of legitimacy for the regime when it is called upon to intervene on behalf of the MEC, even if doing so implies oppression against black workers. At the end of 2012 the country saw 'the most explosive wave of strikes since the end of apartheid' (Ashman and Fine 2012) following the massacre of 34 Lonmin platinum workers by police at a mine in Marikana. This represents an enormous failure by the state to ensure that powerful resource conglomerates enforce or uphold adequate levels of pay and living standards for workers as laid out in the Minerals and Petroleum Resources Development Act. Following Ashman and Fine (2012) 'Marikana epitomises the MEC of today, reflecting both the economic and social failings of post-apartheid development, and the fragmentation, oppression and eruption of dissent to which it has led'.

We suggest that the literature on the MEC contributes to a comprehensive analytical framework for a problem that is at once political, economic, social and technological. It allows for the analysis of historical power relations, structural change and the underlying interests of dominant actors and beneficiaries of governance mechanisms whilst avoiding reducing a complex debate to a technocratic perspective on governance and policy or how to generate a 'policy fix' (Büscher 2009:5). We suggest that it is critical to understand the particular context in which a transition is being studied in order to understand the conditions in which niches might move to regimes and why, as well as the overall context of political and economic landscapes. Historic contingencies play a crucial role in technological change and so attention to the peculiar socio-technical system in South Africa helps to understand patterns of political resistance and technological lock-in that characterise contemporary energy politics. This longer term historical perspective is important because major transformations to socio-technical regimes 'are realised over decades through (unpredictable and often disruptive) evolutionary social and technological change' (Scrase and Smith 2005:708). 
Beyond the MEC, we also make use of broader scholarship from international political economy, including the fractions of capital debate (Holloway and Piccottio 1978; van der Pijl 1998) which has been used to explain on the ability of energy industries to present their interests as those of 'capital in general' because of the close relationship between growth and increases in energy production and consumption (Newell and Paterson 1998). This resonates with the ability of the MEC to present its interests as concomitant with those of 'capital in general' and deserving of state support therefore. This also provides a basis for exploring the extent to which and the ways in which powerful fractions of capital such as finance might be enrolled in a project of de-carbonisation (Newell and Paterson 2010; Perez 2013) which we analyse in the latter part of the paper in relation to the interest among financial institutions in South Africa in clean energy finance and carbon markets. Bringing political economy analysis to bear upon our understanding of the theory and practice of transitions helps to correct the a-political and a-material basis of much transitions theorising to date.

In order to explore these themes the paper analyses three sites of energy policy in South Africa: the Integrated Resource Plan for electricity, the Renewable Energy Independent Power Producers Procurement Programme and the Clean Development Mechanism. These help to illustrate the contested terrain of energy politics in the country and help to shed light on the difficulty and complexity of organising what have been referred to as 'just transitions' (Newell and Mulvaney 2013; Swilling and Annecke 2012) in highly unequal societies. It draws on over 108 interviews with a crosssection of government, business, financial and civil society actors conducted during 2010 and 2011.

\section{Analysing South Africa's embryonic energy transition}

\section{Supporting 'niches' through procurement of renewables}

This section traces a niche intervention in 2007 by individuals within the national energy regulator (NERSA) up to the launch of the procurement process of the renewable energy independent power producer procurement programme (RE IPPPP) and the selection of the first round successful projects in December 2011. Its significance lies in the fact it is the first renewable energy initiative in South 
Africa to have gained traction at the national level. South Africa's RE IPPPP was first conceived in 2007 as the renewable energy feed-in tariff (REFIT), and was at least four years in the making, despite intense interest from renewable energy independent power producers (IPPs) wanting to construct and connect their projects to the country's electric grid. The process faced opposition from within the regulator itself, from the Department of Energy (DoE) and a general resistance within Eskom towards renewable energy. After a delayed start and high levels of uncertainty including the replacement of the feed-in tariff with a competitive bidding system at the eleventh hour, the process was launched in August 2011. It was characterised by an imperfect consultation process, disagreements over the power purchase agreement, grid connection licences, who the buyer of electricity should be and perceived political and financial risks (Baker 2011). The case reveals the roles of different government departments, the private sector, Eskom and the banks, as well as the influence of bi-lateral donors involving interactions between players at the level of the niche, regime and landscape. The episode also illustrates the long-standing power dynamics between NERSA backed by Eskom, and the DoE backed by National Treasury. The process has been paralleled by the increased acceptance of, if not resignation to renewable energy within South Africa's electricity planning and policy arena, and has finally facilitated the entry of renewable energy IPPs into the country's electricity generation.

In negotiating the RE IPPPP there was significant conflict at the national level over whether a competitive bidding system or a feed-in tariff system should be implemented, with the former favoured by the DoE and the latter promoted by NERSA, the private sector and German and Danish bi-lateral donors. Whereas a feed-in tariff sets a fixed price for the purchase of renewable energy higher than that of the retail price for each unit of electricity fed into the grid, a competitive bidding system invites potential project developers to submit bids for a renewable energy contract (Mendonça, Jacobs and Sovacool 2010:174). It was this model which eventually won out. 
The initial push for REFIT came from individuals within the Electricity Regulatory Division of NERSA in 2006/7 who had been inspired by study tours to Germany and Denmark, both of which have a feed-in tariff system. In developing REFIT, NERSA was acting beyond its mandate given that under the 2006 Electricity Regulation Act, it is the DoE's role to make policy and NERSA's to implement it through licensing and regulation (RSA 2006). Yet, as one wind IPP commented, 'if it wasn't for NERSA who took a leading role in pushing REFIT, it may not have happened. NERSA used the Regulator Act to motivate for REFIT to be carried out. They tried to devise a mandate for themselves'. Crucially, 'Thembani Bukula, NERSA's director, brought the world's wind developers to South Africa to beat a path to the DoE's door' according to one energy analyst interviewed. The episode provides an interesting example of a state actor using international business and bi-lateral support to win gains over access to the grid and public subsidies for energy.

By mid to late 2010 REFIT had become high profile and apparently irreversible, at which point the DoE took it over (supported by National Treasury citing concerns over the programme's financial implications), removing it as much as possible from the jurisdiction of NERSA and Eskom and altering the New Generation Regulations on electricity accordingly. In the words of one DoE representative, 'Eskom do all sorts of funny things with IPPs, renewables and planning. The latest version of the Regulations gives all of that back to us. The Minister will determine who does what. This new version of the New Generation Regulations gives the power and control of the procurement process for REFIT back to the DoE'. In August 2011 National Treasury and the DoE declared South Africa's REFIT illegal on the basis that NERSA would determine the tariffs (Aphane 2011). Shortly after, the competitive bidding system was launched, allocating $3725 \mathrm{MW}$ to renewable energy as compared to $1025 \mathrm{MW}$ proposed in the earlier REFIT. Of this, $1850 \mathrm{MW}$ is for wind, $1450 \mathrm{MW}$ for solar photovoltaic and $200 \mathrm{MW}$ for concentrated solar thermal. It constituted a clear attempt by DoE to re-assert control over the issue from NERSA, who backed by Treasury, were seeking to tip the balance of political power in their favour. 
The new RE IPPPP consists of a two tier process in which developers must first demonstrate how they will meet socio-economic development criteria and second submit an offer on price below a certain cap. The selection criteria is weighted 70 per cent on price and 30 per cent on socio-economic criteria which includes factors such as job creation, the involvement of historically disadvantaged individuals and localisation of components (Creamer 2011b). However, the price submission will only be considered once the socio-economic criteria have been met by the bid that meets the requirements at the lowest price winning the contract. Bidders also need to raise a bond of R100 000 (nearly \$USD 11,000) for every MW of capacity eventually bid. The first bid submission date was set for 4 November 2011 and the selection of preferred bidders took place in December 2011 to coincide with the UNFCCC conference in Durban.

Industry bodies such as the South African Wind Energy Association (SAWEA) expressed their distrust of REBID as compared to REFIT which they claimed was relatively less complex, lower in compliance costs and greater in investor certainty. The alignment with the renewable energy industry engendered by the REFIT process under NERSA and the trust built up was compromised by REBID's 'unilateral process without any public consultation and with uncoordinated statements in the press' (SAWEA 2011). Whereas under NERSA, relevant documents were publicly available and followed by public hearings, the new REBID documents are subject to a fee of R15 000 (\$USD 1,647) and subject to stringent confidentiality requirements. SAWEA also complained that the socio-economic requirements were also ‘very high' (Creamer 2011a) and saddled a young industry with a heavy and unanticipated compliance burden. Sceptics suggest that the secrecy of the RE IPPPP 'serves to fuel concerns that a whole gamut of parasitic and non-value-adding parties were lining up again for an even bigger feeding frenzy than that of the R30 billion arms deal, the Chancellor House involvement in the Medupi and Kusile boiler contracts, and other major public sector procurements' (Yelland 2011). 
While the process was finally launched, and has since gone through two rounds of approvals, its negotiation can still be cited as an example of what has been described by Scrase and Smith (2009:720) as a 'descent into pork-barrel politics' in the creation of a process through which large numbers of potential entrepreneurs can access funds for niches. Such a concern was expressed repeatedly in 2010 by a variety of interviewees with regards to REFIT's design and implementation in light of the scramble provoked by its very lucrative tariffs proposed in 2009 . The generosity of the proposed tariff generated a vast amount of interest from IPPs resulting in a 'wind rush' of aspiring developers to South Africa some of whom had no or limited experience. Nevertheless, participation in this process appears to have favoured companies with large corporate assets in light of the time and the uncertainties involved and the huge up front capital requirements for an independent renewable energy producer. As one wind energy producer explained "big internationals can take the risk. They have deep pockets, time and lots of capacity". IPPs bring their own finance, invest at their own risk and only get paid when their project is connected to the grid and starts to deliver.

Many parties interviewed in 2010 considered these tariffs to be too high (the proposed wind tariff was R1.25 per kWh (\$USD 0.137) for example), claiming that they would create an unnecessarily lucrative profit for IPPs at the expense of the electricity consumer which would hit the poorest the hardest. There were also questions about the ability of the national public purse to sustain such generous levels which would be set for a 20 year term and linked to South African inflation. Analysis by SARi (South African Renewables Initiative) at the end of 2010 found that 'expected costs required in South Africa are significantly lower than suggested by the current level of REFIT, particularly for wind' and that the anticipated risk premium had been overestimated (SARi 2010:21). Fears were also raised that the high tariffs would create corruption in the bidding process given the extreme competition for what at the time was only $1025 \mathrm{MW}$ of capacity (Salgado 2010). An Eskom representative commented: 'right now, decisions on who gets REFIT tariffs are very subjective. This could lead to lawsuits, which would stall the process of creating a sustainable renewable energy industry even further and have serious financial implications'. ${ }^{5}$ 
Integrated resource plan 2010: technological lock-in or a regime in transformation?

National electricity plans potentially provide an opportunity to provide precisely the sort of integrated goal oriented management plan that TM literatures would encourage and which have been analysed in the case of the Netherlands (Kern \& Smith 2008). Though not constituted or rationalised in those terms, South Africa's Integrated Resource Plan (IRP 2010) for electricity is a master plan for the national electricity generation mix. The significance of the document is that generation projects must be in line with the technological limits set by IRP 2010 in order to be granted a generation license by the national energy regulator (Pienaar and Nakhooda 2010).

Approved in May 2011, IRP 2010 aims to double national generation capacity from approximately 41,000 MW to $89,532 \mathrm{MW}$ by 2030 . This has been misguidedly celebrated in some arenas for diversifying the country's energy mix away from coal and allowing for the introduction of 23,559 MW of grid-connected renewable energy (of which 9,200 MW will come from wind, 8,400 MW from solar photovoltaic (PV) and 1,200 from MW concentrated solar power (CSP) (DoE 2011:14). Although the mix has incorporated renewables, of which the majority will come from IPPs, the doubling in overall capacity will still lead to increased national greenhouse gas emissions. This is because in absolute terms, 16,383 MW of new coal will be introduced to a total of 41,071 MW even though proportionally it decreases from 85 to 46 per cent (DoE 2011:14). An ambitious nuclear fleet is also planned whose cost has yet to be determined.

\section{Doubling demand}

\section{Figure 2 here}

Winkler's (2011) analysis suggests that the IRP would result in 'GHG emissions from electricity generation increasing from 237 million tons of CO2 in 2010 to 272 million tons in 2030'. It will also increase electricity prices, 'by at least 250 per cent in real terms from their current level by 2020 and by a much higher rate with inflation factored in' (Winkler 2011). This doubling in electricity capacity 
serves to fuel a demand forecast which anticipates a double fold increase in mining and minerals beneficiation and coal-to-liquids technology as shown in figure 5, something which was referred to by a representative of the City of Cape Town's climate and energy branch in December 2010 as "business as usual on steroids" (in Donnelly 2010).

The way in which this plan was negotiated is revealing of the political economy of electricity in South Africa. While the participatory nature of its public consultation process was welcomed, a 'technical advisory group' which provided inputs into the modelling process was heavily criticised for consisting largely of representatives from coal miners, the energy intensive users group, Eskom and government. Described as a 'Who's Who of the coal-mining and energy-intensive users in South Africa' (Greyling 2010), it failed to include representatives from the renewable energy industry, civil society or experts from the fields of social impacts and environmental quality. Confirmation of the committee's existence and the names and affiliation of its members was only made public in June 2010 after the Minister of Energy responded to a civil society request for information (see Peters 2010). The committee's meetings and its minutes were not made accessible to the public and all of its members signed confidentiality agreements with the Department of Energy. Civil society groups expressed concern that the modelling process on which the committee was advising was likely to reflect the industrial bias of the interests of its members (McDaid et al 2010:6). A letter from the Minister's office of 21 June 2010 responding to civil society's requests for information on the committee took 'exception to the classification of [its] Technical Task Team as secretive' and that the members of the task team were chosen for their technical expertise and 'are not meant to represent the interests of their constituencies/employer organisations' (Peters 2010).

Not only does this process illustrate that an apparently technical exercise, such as electricity modelling can be inherently political, it also reveals the level of institutional power traditional MEC stakeholders have, expressed as privileged access to decision makers, and the influential role that regime incumbents continue to play in electricity policy making in South Africa. This is in spite of the incremental steps to enter the regime made by emerging renewable energy players and indeed the 
nuclear industry. Finally, despite its transformative potential, the plan may merely perpetuate highcarbon technological lock-in. In May 2011, journalist Troye Lund (2011) explained,

"Government has been insistent the IRP is a "living document" and not cast in stone: it will and can be changed as and when new technologies develop. However, the reality is that once an energy plan such as the IRP is approved - and once the State is locked into huge fleet contracts for the relevant new coal or nuclear power stations - it will be difficult, if not impossible, to get out of them. Furthermore, if funding is committed to those power stations, that spending will hinder any potential for investment in renewable or cleaner energy technologies as and when they come on line'.

The IRP 2010 process demonstrates that emerging niche actors in private renewable energy generation, supported by actors at the landscape level, have clearly had some success in achieving a certain level of change in the electricity mix. However, the extent to which they can compete for resources and access to the grid with entrenched vested interests who have more access to and influence over decision makers in government remains in doubt. Moreover, in terms of assessing the degree of transition away from a fossil fuel based economy this case study reveals that the benefits gained from the introduction of renewable energy IPPs are overwhelmed by the introduction of further coal-fired electricity and a national industrial demand based on energy intensive end-user practices which remain fundamentally un-altered. In essence, energy intensive interests continue to dominate in the electricity sector at the level of supply and demand. This confers upon them a degree of material power which is exercised in the setting of policy. Swilling and Annecke (2012: 227) sum it up the following way: '...the IRP leaves unchallenged Eskom's business model - centralised production via few large plants, dominance of non-renewable energy, grid-base delivery with no storage and limited roles for independent power producers'. This is unsurprising when it is recalled that the IRP is based on a demand forecast compiled by Eskom based on confidential data that was never independently verified. Moreover, it is aligned neither with the LTMS, the New Growth Path (NGP) nor the emissions intensity pledge made at Copenhagen in December 2009. Despite changes in 
the generation mix, the 'uniquely electricity intensive' (Fine and Rustomjee 1996:8) nature of South Africa's coal-fired economic growth strategy has not changed.

\section{Table 1 here}

\section{Landscape drivers of change? The role of carbon finance}

Generating and sustaining flows of finance to support technology development and diffusion is critical to socio-technical transitions. Beyond the forms of domestic subsidy discussed in relation to the RE IPPPP, international finance represents an increasingly important source of support to domestic innovations aimed at lowering carbon emissions. In transition terms, there are questions over how international finance interacts with and alters the political landscape in South Africa. In particular whether South Africa's relationship to institutions such as the World Bank and UNFCCC (United Nations Framework Convention on Climate Change) and initiatives such as the CDM or Clean Technology Fund will support niche development or are rather more likely to strengthen the incumbent regime.

South Africa has managed to secure access to international climate finance through the World Bankadministered Clean Technology Fund. South Africa's Planning Minister Trevor Manuel is also one of three co-chairs of the transitional committee overseeing the design of the Green Climate Fund set up by the Copenhagen Accord to disburse US $\$ 100$ bn per year by 2020 , with the World Bank as the interim trustee, and previously served on the High-Level Advisory Group on Climate Change Finance. South Africa also hosts projects funded through the UN's CDM. The CDM is a global offset mechanism which allows Annex I industrialised countries under the Kyoto Protocol to pay developing countries to reduce emissions where it is cheaper to do so, on the understanding that projects supported through this means also generate sustainable development benefits in countries where they are hosted. Whereas countries such as India and China have attracted the lion's share of over 5000 
registered CDM projects to date, African countries have only recently seen the registration of the $100^{\text {th }}$ project on the continent, with 22 of these being hosted in South Africa, only 10 of which have yet been fully implemented and issued with Certified emission reductions (CERs) (Fenhann et al. 2012). There are a number of reasons for this poor ability to attract projects which include elements of the existing political economy of energy in South Africa that has created a lack of incentives in a country with historically low electricity prices such that investments in energy efficiency have until recently been lacking. 'Business climate' factors also play a role, such as poor infrastructure, corruption, low availability of equity investment and debt finance and an inadequate skills base among the labour force. There is also a lack of political commitment and leadership on the part of the South African government to use carbon finance to support and add value to domestic policy priorities. Barriers specific to the CDM's governance in South Africa include claims of opaque approval procedures and poor quality project validation and verification agencies (Designated Operational Entities, DOEs) that sign off on projects and thereby allow the credits to be released. Views among businesses interviewed for this research vary on the effectiveness of the South African government's direct management of the CDM through its Designated National Authority (DNA), but in the absence of proactive government policy and lack of interest on the part of many firms, the $\mathrm{CDM}$ in South Africa has been primarily driven by consultants looking to promote the development of projects and in doing so creating a stream of consultancy contracts.

Many RE developers are now keen to benefit from the CDM in order to further capitalise on openings in the market created by the RE IPPPP. However investors rue the lack of government leadership in promoting and enabling the financing of energy projects through the CDM in South Africa. This is attributed to a range of factors, including a lack of capacity (few and under-trained staff) and recent budget cuts for regional workshops to promote the CDM. ${ }^{6}$ It has also been suggested that there is and a reluctance in government to support private sector profits where rents cannot be accrued to the state. $^{7}$ While there is interest from South African national banks such as Standard Bank and NedBank in investing in renewable energy projects and benefiting from CERs, early hype about the easy pickings to be gained from CDM projects put about by consultants in late 2010 quickly gave way to a 
realisation of the significant transaction costs associated with financing and steering a project through the CDM approval process before CERs are issued and a return on investment is realised. ${ }^{8}$

Domestic initiatives such as those discussed above have, nevertheless, given a boost to interest in the CDM. Early concerns that the first REFIT (now RE IPPPP) tariff would render CDM finance unavailable on the basis that projects would no longer be able to demonstrate financial 'additionality', gave way to optimism about how different domestic and international funding streams could be blended to support niche technologies. It is ironic then that this occurred at the very time that South Africa's ability to benefit from the CDM was cast in doubt by proposals from the EU, far and away the largest buyer of CERs, to buy carbon credits from 2013 from only least developed countries that have thus far largely failed to benefit from the CDM (Emissions EUETS 2013). This confluence of political factors has led some to claim that South Africa has 'missed the boat on CDM'.

Opponents of carbon trading meanwhile have argued that the effect of the CDM in South Africa's has been powerful but negative. The impact has been to reinforce existing patterns of social injustice and environmental destruction (Bond 2009; Reddy 2011): providing a financial life line to polluting landfill sites such as Bisasar Road in Durban, for example, or creating revenue streams for actors such as Eskom, which is developing CDM financed light bulb replacement projects, and other MEC actors such as the petroleum and chemical giant, Sasol. ${ }^{10}$ Indeed, eighty per cent of CDM revenue in South Africa to date has been captured by four out of a total of 22 projects that reduce nitrous oxide emissions from industrial nitric acid production (Fenhann et al. 2012). Of the other 18 projects registered projects, South African industrial interests and the non-renewable electricity projects are well represented, including Steel (Transalloys), Brick (Corobrick), Paper \& Pulp (Sappi Kraft), Agribusiness (Tongaat, Omnia Fertiliser), Oil (PetroSA), mining (GFI South Africa), and the capture of methane from landfill sites for electricity production (six public municipalities). In this sense, both the number of projects developed and the lion's share of CERs produced in South Africa have further entrenched the power of elite industrial actors central to the country's minerals-energy complex, and whose main interests lie in the production and/or use of fossil fuels and in energy intensive industrial 
processes. These actors have the financial resources to afford the transaction costs associated with registering and managing a CDM project and high levels of institutional access to secure government support and approval for their projects. This experience seems to support the trend foreseen by the earlier studies whereby: '..credits would most likely end up with already dominant companies in emerging economies, because of, for example, their size, technical and/or political savvy, access to resources and management, and sheer economic weight ... This risk is even greater if companies continue to be state-owned or close to the government' (CEPS and WBCDS 2008: 34.)

As a landscape actor meanwhile, the World Bank has played a role in trying to stimulate interest in carbon markets using its financial power to promote the desirability of market based mechanisms through the Prototype Carbon Fund, for example, which sought to buy up credits for projects in the early days of the CDM. It has also supported its own idea of 'clean energy' through a controversial loan to the Medupi coal-fired power station in South Africa. This loan, made directly to Eskom and underwritten by the government was the largest loan that the South African government had ever negotiated with the World Bank. The loan was justified as 'clean' on the grounds that the plant was designed to use super-critical coal technology and because of World Bank loan conditions for the retrofitting of Flue Gas Desulphurisation (FGD) technology, the construction of two small renewable energy projects, energy efficiency measures, and that Medupi be made 'Carbon Capture and Storage (CCS) ready' (Baker 2012). This is consistent with the mandate of the MDBs to cover the 'incremental costs' of providing a global environmental benefit, and provides a large scale, high profile example of how clean energy infrastructure and finance has been mobilised in ways that are dependent on existing systems.

Whether future climate finance for 'clean energy' comes from carbon markets or other sources of mitigation finance, the issue will be same: whether it is of a scale and predictable continuity that will shift the calculus of powerful state and private actors rather than be seen as something which merely reduces risk and adds value to existing projects, 'the cherry on the top of the cake' as one interviewee 
put it. ${ }^{11}$ Securing carbon financing is more often than not an 'afterthought' once the viability of a project is already established, ${ }^{12}$ but does not in and of itself have sufficient financial weight, or bring with it powerful enough incentives to support more substantial change in energy policy. When plans for RE IPPPP looked to be approaching implementation, the DNA reported a significant increase in the number of expressions of interest in Project Idea Notes (precursors to full CDM project design documents) submitted from potential renewable energy IPPs. More projects in the South African $\mathrm{CDM}$ pipeline are now designed to generate renewable electricity. Eighteen of the 59 projects awaiting validation are wind projects. This is in contrast to 22 currently registered projects which target the installation of only 50MW and contain only two renewable electricity projects, in addition to eight projects that generate electricity from the capture and flaring of methane from landfills and industrial processes. The dynamic also works the other way around. Many interviewees noted at the time of the NERSA wind tariff revision that it could make CDM more popular, to plug the shortfall that IPPs were facing relative to the initial tariff. It is telling that in IRP 2010 the 40 per cent of new electricity generation anticipated from renewable energy envisaged REFIT as the driver of investment, not the CDM or other forms of external finance given the uncertainties associated with them. ${ }^{13}$ As one project developer put it: 'if there's one thing I've learned it's don't base your business on carbon revenue... basing it on carbon increases risk'. ${ }^{14}$ It is therefore also notable that the sum of the installed capacity of South African CDM wind projects awaiting validation (2690 MW) is greater than that allocated to wind energy by the RE IPPPP (1850 MW), suggesting first that wind IPPs are targeting the CDM as an additional source of finance alongside RE IPPPP bids, and second that many of these CDM projects will not be viable unless they are successful under the RE IPPPP.

To gain more traction, there is a stronger case that also needs to be made about the co-benefits and contributions to sustainable development that carbon finance through the CDM is intended to bring. Job creation and sustainability, in particular, could be emphasised further, in order to engage the interest of more powerful ministries such as the Department of Trade and Industry (DTI) and others who are seeking to tackle the economic disadvantage of the historically marginalised population. ${ }^{15}$ In this sense CDM and other such funding flows 'have to fit into national policy objectives', as the head 
of the country's DNA put it. ${ }^{16}$ The approval of CCS methodologies by the CDM Executive Board in Durban 2011 may serve to generate more interest in that regard.

\section{Accommodation and Resistance}

What can we discern from the above discussion about the shifting terrain of energy governance in South Africa? Overall it is clear that resistance to profound change is strong and entrenched, in spite of a number of progressive developments aimed at encouraging a greater share of renewable generation in South Africa's electricity mix as a means of enhancing energy security, taking their immediate cues from a series of threats (such as the electricity supply-side crisis where blackouts cost the economy US\$7.1 billion (1.4\% of GNP) in 2007/08) (Swilling and Annecke 2012:227), as well as opportunities for South Africa to position itself as the renewable energy capital of Africa. The economy remains heavily dependent on energy intensive resource extraction industries that are lobbying hard against increased production costs from measures such as the proposed carbon tax and some still benefit from contracts which tie the state to the provision of cheap electricity that will likely be fossil-fuel based. While some, such as the mining giant Exarro, are investing in renewable electricity generation largely as hedging strategies as well as anticipating potential domestic developments, their core business remains in fossil fuels.

Likewise, while there is interest on the part of Eskom to take pressure off the grid through schemes such as the solar water heater programme which aims to oversee the roll-out of 1 million such heaters by 2013 , commitment to a fossil fuelled grid remains strongly intact. Though perhaps not the 'gods' they once were, as one interviewee referred to them, ${ }^{17}$ Eskom continues to be a formidable force that will not easily concede its position of power. ${ }^{18}$ As Fine and Rustomjee note, Eskom 'fulfilled a particularly important function in lubricating both the growth of MEC core sectors and the ascendance of large-scale private capital' (1996:97). Though it evaded the global trend of power sector liberalisation in the $1980 \mathrm{~s}$ and $1990 \mathrm{~s}$ as a result of which it kept its monopoly position, it was improperly managed as a state enterprise which, it can be argued, was a key factor in the electricity deficit that the country now faces (Bekker et al 2008, Steyn 2006). In transition terms, whilst niches 
have gained some level access to the regime, with support from landscape actors, South Africa's coalgenerated electricity regime has thus far been able to resist pressures for more profound change and to apply the brakes on more radical notions about how to advance a low carbon economy in favour of more incremental forms of change which preserve, or even enhance, the power of incumbent actors with whom the government enjoys close relations and which constitute a key part of its power base. It may also be the case that the incumbent regime is not actually threatened by low carbon initiatives which thus far are taking place in parallel to additional investments in coal, as well as lending support to them in the case of clean coal, rather than replacing them in any meaningful sense. As Goldthau and Sovacool (2012:235) state, "new technologies may succeed only if they can "add on" to the incumbent system i.e if they are compatible with the system's dominating features. By definition, this prevents radical change'.

The incumbent regime is not monolithic or static, but incorporates an industrial complex which includes big capital in the form of BUSA, 'the collective voice of industry'19 and the Energy Intensive Users Group. There is, therefore, a powerful alliance of capital sceptical towards attempts to diversify the energy base and often resistant to change which, it is feared, may increase production costs or bring about job losses. The power of this bloc is sustained on a material level through control of production and their role in the financialisation of the South African and the global economy (Ashman et al 2011) as well as institutionally through arrangements which grant them privileged access to key ministries such as the DoE as illustrated in the case of the IRP 2010. This bloc has been able to position itself as advancing the interests of capital in general and to show how this is aligned with key state objectives. As has been shown elsewhere (Newell and Paterson 1998), it is relatively straightforward to argue that cheap energy is central to growth and to the economic health of all sectors of the economy, such that powerful energy industries find it easier to present their particular interests as those of 'capital in general'.

The position of trade unions within the incumbent regime is important, though perhaps less clear. The issue is not only one of jobs, but also that the majority of renewable energy will be generated by 
private producers where there is a strong preference for generation to remain under public control. For instance in February 2012 the National Union of Metal Workers of South Africa (NUMSAO said it would try to prevent the renewable energy sector from being dominated by a capitalist system and that workers and communities are at risk of being left behind and 'being forced to pay the costs of the sector's expansion' (Algoa FM 2012). Rhetorically at least there is an embrace in some quarters of the trade union movement nevertheless, of arguments about 'green jobs' and the 'just transition'. The International Trade Union Confederation at a workshop in Durban in July 2011, for example, stated;

'Climate is also our issue because addressing it implies recognising the need for a huge transformation in our societies, in our production and consumption systems, and therefore also on jobs. Leadership by the labour movement is needed for transforming the system. Unless we fight for making this transformation work for the people, ensuring a Just Transition towards a truly sustainable model, we will only see superficial changes towards more inequality and environmental degradation' (ITUC 2011).

We noted earlier, however, a rising commitment, rhetorically at least, to building a 'green', low carbon economy embodied in the New Growth Path of 2011, even if many of its intentions are contradicted by the IRP that was adopted at the same time. In 2010 the cabinet approved a DEA (Department of Environmental Affairs) document on Green Jobs: A South African Transition and thereafter the Industrial Development Corporation (IDC) and Development Bank of South Africa (DBSA) worked with the DEA to develop financial plans for implementing a green economy strategy. The Industrial Policy Action Plan also acknowledges that rising energy costs 'render our historical capital and energy-intensive resource processing based industrial path unviable in the future' (DTI 2010). This framing of South Africa's predicament and the extent to which transition to a lower carbon economy can be experienced as an opportunity rather than a threat remains to be seen and will undoubtedly be a product of precisely the sorts of political struggles and bargaining among competing coalitions that we have described in this paper.

From electric capitalism to climate capitalism? 
'Our economic growth over the next decade and beyond cannot be built on the same principles and technologies, the same energy systems and the same transport modes that we are familiar with today' (South Africa's Minister of Finance, Parliament, February $20^{\text {th }} 2008$ )

This final section of the paper speculates briefly on the prospects that South Africa might transition away from what McDonald (2009) calls 'electric capitalism' to describe the way in which the current electricity regime in (South) Africa entrenches and embeds existing inequalities through its uneven development and levels of access while locking in a carbon-intensive development path, to a form a form of 'climate capitalism' in which capitalism's growth imperatives are increasingly served by the creation of new sites of accumulation in a low carbon economy (Newell and Paterson 2010).

Although it is beyond the scope of this paper to propose what a "coalition of the willing and the winning' capable of driving a shift towards a lower carbon economy in which national development objectives are met through low carbon energy in South Africa might look like, we make the following brief observations. First, there is interest in business associations that are globally networked in opening up opportunities to attract foreign capital into the 'clean energy' sector in South Africa as well as preparing domestic firms for the reality of competition in an increasingly carbon-conscious global economy in which buyers, following the lead of Walmart and other major retailers, may be more attracted to those businesses and suppliers in South Africa that can provide evidence of a commitment to reduce their carbon emissions. An example here is the National Business Initiative, the local partner of the World Business Council for Sustainable Development that has been promoting the 'business case' for action on climate change in South Africa through, for example, participation in the Carbon Disclosure Project (CDP) whereby firms disclose their carbon footprint and are ranked accordingly. ${ }^{20}$ The CDP now reports on the top 100 firms listed on the JSE.

Second, in broader debates about the carbon economy, the role of finance often features centrally (Newell and Paterson 2010) as a potential lever of change given the heightened power of finance capital in the contemporary global political economy and the obvious need to drastically scale up financial investment in clean energy if climate change policy objectives are to be successfully 
realised. Finance also features highly in historical accounts of waves of innovation and transition (Perez 2002, 2013). In South Africa's financial sector, centred on the Johannesburg Stock Exchange, there is interest in investment in clean energy and in carbon markets. South Africa's largest national banks such as $\mathrm{ABSA}^{21}$ NedBank and Standard Bank are also involved in renewable energy project finance and the CDM. Though not yet developed, market instruments such as Tradeable Renewable Energy Certificates, might bring into a being a constituency of business actors, particularly finance, with a material interest in low carbon development

However, the role of finance in the MEC (Fine and Rustomjee 1996) and evidence of these same banks funding large-scale new investments in further fossil fuel development should caution against too much optimism on this front. It is clear that the core interests of much finance capital in South Africa rest firmly in carbon intensive industries with their involvement in renewable energy being thus far largely token, not unlike trends at the global level. According to Carbon Tracker (2012:4) companies listed on the Johannesburg Stock Exchange (JSE) have coal reserves equivalent to 38.90 giga tonnes of $\mathrm{CO}_{2}$. Together with Eskom the JSE 100 companies account for 64 per cent of the country's total estimated emissions (approximately 510 million $\mathrm{tCO}_{2} \mathrm{e}$ ) (CDP 2012:9).

Until there are stronger signals emanating from government about the direction of change in energy policy, finance capital will continue to seek easy and profitable returns in MEC sectors. Meanwhile, efforts by landscape actors such as the African Development Bank and World Bank to stimulate investments in renewables, alongside donor funded initiatives such as the South African Renewables Initiative (SARi) that aim to engage private finance in providing support for lower carbon energy, are dwarfed by their continued lending to fossil fuel projects.

Persuading and engaging powerful actors in the state that viable accumulation strategies exist in a lower carbon economy from which their political allies, largest donors and tax payers and key political constituencies can benefit, will be decisive to their success. There may be some tentative signs of change in this regard. As discussed in relation to the RE IPPPP, Eskom no longer poses the same political barrier to renewables since the procurement process was removed from its jurisdiction 
by the DoE, leaving it less able to use its power to exclude access to the market it dominates. It is rather the case that the company's strategies are aimed at preserving their share of the market in the face of competitive threats from new market entrants. Indeed Eskom's sustainability strategy includes climate change as a priority area and there is interest in renewables, 'smart grids' and accessing carbon finance and making use of the CDM to diversify SA's energy options. Yet those pushing renewable energy within the utility concede that this represents 'an uphill battle', particularly among middle managers ${ }^{22}$ since the utility's core business and expertise still lies in coal-generated electricity.

The problem is that without a clear strategy and set of concrete commitments for moving towards a lower carbon economy that go beyond discursive commitments to the 'green economy', policy may instead and by default continue to be characterised by muddling through, allowing a variety of technologies and generation options to unfold while seeking to protect the positions and interests of key corporate allies and labour vis-à-vis the accumulation and employment implications of particular energy futures. We can see this in the ad hoc policy shifts that have occurred thus far, reacting to resource constraints 'without necessarily developing the institutional capacities... to manage a more holistic nationwide transition' (Swilling and Annecke 2012: 240).

\section{Conclusions}

We have argued in this paper that in order to adequately understand the contested politics of energy transition in South Africa where a number of 'low carbon' initiatives are tentatively being introduced, greater attention is required to the political economy of transitions which highlights the relations of power and the importance of politics that, we argue, are decisive in enabling or frustrating the potential for change in the energy sector. We have suggested that the literature on the MEC, in particular, grounded as it is the South African context, provides such an account. At the same time, we would suggest that whilst academic insights from work on the MEC and the centrality of statecapital relations are useful, they have yet to fully engage with embryonic moves towards diversifying South Africa's energy base. ${ }^{23}$ Work on pathways and the way these are contested: prioritising and privileging, as well as excluding, particular framings of energy problems, technologies and therefore, 
policy responses helps to emphasise the contingency and uncertainty of transition pathways even in the face of a powerful incumbent regime (Byrne et al 2011).

So what has been revealed by our attempt to bring political economy to bear upon the transitions literature in order to understand contemporary energy politics in South Africa? First, it has drawn attention to the power of incumbents organised around deeply entwined and overlapping networks of economic and political power enshrined within the MEC. We have seen this in the close relations between the South African state in and the EIUG in particular. In concrete policy terms the ties are revealed in the constitution of key decision-making bodies such as the DoE Technical Task team created for the IRP.

Second, our approach has emphasised the importance of historical trajectories and lock-in: the drive for energy self-sufficiency and independence, the apartheid legacy which constructed energy access along racial lines, and the 'sweetheart' deals offered to mining and energy companies under apartheid to invest in a country ostracised by the international community (Yelland 2010). This racialised history is also relevant to understanding the suspicion held by some elements of organised labour and civil society of white elites backed by foreign investors accruing power and wealth through opportunities opened up as part of a transition, in particular around the RE IPPPP (Baker 2011). It also explains the centrality of questions of justice, distribution and the role of labour in transitions which must be addressed more systematically in transitions literature if the possibilities of a 'just transition' are to be understood and acted upon.

Third, both through our emphasis on landscape factors in the transitions literature and political economy literatures grounded in South Africa' experience, we have been able to understand and explain the critical interplay between internal drivers of change and exogenous factors. In examining South Africa's energy governance we have shown how international donors and development banks, and global carbon and energy finance have impacted upon the balance of social and political forces shaping South Africa's energy future. 
It is in the fusion of political economy literatures with those on social-technical transitions to conceptualise energy governance that we suggest useful insights might be yielded into the power relations inhibiting and enabling change in other countries where the challenges of enabling a low carbon transition are every bit as acute as in South Africa. In the first instance such an approach might be usefully applied in other settings where something resembling a minerals-energy complex operates, such as Chile and Australia, without disregarding the unique historical, material and political context within which transitions are expected to occur or may be just beginning.

The literature on transitions provides useful insights into the drivers of change and the actors that have to be on board for technologies and sectors to move from niche to widespread adoption. Where they often fall short is on exploring the underlying political economy of transitions: the exercise of power by state and corporate elites that can block change until such time as the interests of capital in general are perceived to be served by an alternative energy base. Given the strength of the incumbent regime in the form of the MEC that is so tied to and reliant upon the production of cheap fossil fuels and their distribution through a grid controlled by a virtual monopoly actor, opportunities for large-scale and widespread transitions are hard to discern. Instead, the embrace of energy alternatives by the incumbent regime is likely to be slow and reactive to crises of energy supply and demand rather than opportunity-driven.

Our analysis has shown that debates about low carbon transitions need to be attentive to the diversity of economic, political and social contexts in which transitions need to, and to some extent are starting to occur, if they are to retain relevance outside of the high-income country settings in which many of them were developed. The pressing need to address poverty and social and racial inequality in a society such as South Africa significantly magnifies the nature of the challenges ordinarily associated with delivering transitions. The 'nature' of the country's economic base and the close ties between political and economic elites narrows opportunities for change. Moments of crisis create opportunities for change, nevertheless, and the changes in the landscape and regime that we have outlined above suggest an alternative set of strategies and development vision, albeit far from dominant, may 
tentatively be on the ascendancy, combining foreign public and private finance with domestic interest in identifying viable accumulation strategies in the provision of non-fossil fuel energy to a rapidly growing economy. As Swilling and Annecke (2012: xiv) note: 'The notion of a 'transition' has a specific meaning and history in South Africa'. Because of the history of apartheid, South Africans are acutely aware that transitions are deeply political, involve struggle against powerful and deeply entrenched interests, and take years if not decades to bring about. 


\section{References}

Algoa FM (2012) 'NUMSA: Prevent capitalist grab of renewable energy', Algoa FM, 5 February http://www.algoafm.co.za/article.aspx?id=570, Accessed 30 July 2012

Aphane, O. (2011) 'Renewable Energy Programme for South Africa: Are we going backwards or forwards?' DoE Power point presentation EE publishers panel discussion and debate, Midrand, 23 August 2011.

Ashman, S., B. Fine, et al. (2011). 'Amnesty International? The Nature, Scale and Impact of Capital Flight from South Africa.' Journal of Southern African Studies 37(1): 7-25.

Ashman, S. and Fine, B (2012) 'South Africa: The Meaning of Marikana', Think Africa Press, 14 December 2012

Baker, L. (2011) 'Governing electricity in South Africa: wind, coal and power struggles', The Governance of Clean Development Working Paper 015 - July 2011. Norwich: University of East Anglia.

Baker, L. (2012) 'Governing power in South Africa: the political economy of socio-technical transitions', Conference Paper presented at the International Conference on Sustainability Transitions, Copenhagen, 29-31 August 2012

Bekker, B., A. Eberhard, et al. (2008). 'South Africa's rapid electrification programme: Policy, institutional, planning, financing and technical innovations.' Energy Policy 36(8), pp. 3125-3137.

Bond, P, H. Chitonge and A. Hopfmann (eds). (2007) The Accumulation of Capital in Southern Africa: Rosa Luxemburg's Contemporary Relevance. Berlin, Rosa Luxemburg Foundation and Durban, Centre for Civil Society.

Bond, P. (2009) 'In "power”' in Pretoria'. New Left Review, 58, July-August, p.77-88. 
Büscher, B. (2009) 'Connecting political economies of energy in South Africa'. Energy Policy 37(10): 3951-3958.

Byrne, R., Smith, A., Watson, J. and Ockwell, D. (2011) Energy Pathways in Low-Carbon Development: From Technology Transfer to Socio-Technical Transformation, STEPS Working Paper 46, Brighton: STEPS Centre

Carbon Tracker (2012). Unburnable Carbon: budgeting carbon in South Africa http://www.carbontracker.org/southafrica Accessed 12 January 2013

Carbon Disclosure Project (2012). South African business: shifting the focus to performance, CDP South Africa 100 Climate Change Report 2012 https://www.cdproject.net/CDPResults/CDP-SouthAfrica-Climate-Change-Report-2012.pdf Accessed 13 January 2013

Carnie, T (2010). ‘Sour taste over sweetheart deals'. The Mercury, 18 March 2010

Center for European Policy Studies and World Business Council for Sustainable Development (CEPS and WBCSD) (2008) Global sectoral industry approaches to climate change. Brussels:

CEPS and WBCSD.

Creamer, T. (2011a) 'Renewables bid represents 'substantive progress', but raises compliance burden', Engineering News, 23 August

Creamer, T. (2011b) 'DoE reports big interest in renewables tender', Engineering News, 31 August

Creamer Media (2011) Electricity: a review of South Africa's electricity industry. Creamer Media's Research Channel Africa, February 2011

CURES (2009). 'Exploring Energy Poverty in South Africa'. CURES, Midrand. www.cures.co.za

Das, K. (2011) Technology transfer under the Clean Development Mechanism: an empirical study of 1000 CDM projects. The Governance of Clean Development Working Paper 014. Available at: www.uea.ac.uk/dev/gcd/Das+2011?mode=print/ accessed October 24 2012 . 
DoE (2011) Electricity Regulation Act No.4 of 2006, Electricity Regulations on the Integrated Resource Plan 2010 - 2030 ('Policy-Adjusted IRP'), Government Gazette, Pretoria, 6 May 2011

Donnelly, L. (2010) 'Resource plan gets dim reception.' Mail and Guardian, 6 December

DST [Department of Science \& Technology] (2007) Innovation Towards a Knowledge-based Economy: Ten-year Plan for South Africa (2008 - 2018). Pretoria, DST.

DTI (2010) Industrial Policy Action Plan 2012/13-2014/15 Pretoria: Department of Trade and Industry.

EarthLife (2013) 'Renewable Energy is Peoples' Power' www.earthlife.org.za/?page id=193 Accessed 15 January 2013.

Eberhard, A. (2007). 'The Political Economy of Power Sector Reform in South Africa'. In D. Victor and T. C. Heller. Cambridge, Cambridge University Press

Edkins, M., A. Marquard and H. Winkler (2010), Assessing the effectiveness of national solar and wind energy policies in South Africa, for the UNEP research project 'Enhancing information for renewable energy technology deployment in Brazil, China and South Africa, Cape Town: Energy Research Centre, University of Cape Town, June 2010

Emissions EUETS (2013) 'CERs and ERUs market as from 2013', www.emissions-euets.com/cerserus-market-as-from-2013 Accessed 15 January 2013.

Eskom (2011) Partnering for a sustainable future, Integrated Report 2011

Fenhann, J., 2012. CDM Pipeline Overview. UNEP Risø Centre, Roskilde. Available at: www.cdmpipeline.org, 1 December 2012.

Fine, B. and Z. Rustomjee (1996) The Political Economy of South Africa: From Minerals Energy Complex to Industrialisation Boulder: Westview Press. 
Fine, B. \& Rustomjee, Z. (2008) 'Debating the South African Minerals-Energy Complex: A Response to Bell', Development Southern Africa 15(4), pp. 689-701.

Fine, B. (2008) The Minerals-Energy Complex is Dead: Long Live the MEC? Paper presented to the Amandla Colloquium Cape Town 4-6 ${ }^{\text {th }}$ April (Unpublished).

Foxon, T., G. Hammond, P. Pearson (2010) 'Developing transition pathways for a low carbon electricity system in the UK', Technology Forecasting and Social Change 77(8), pp. 1203-1213.

Freund, B (2010) 'The significance of the minerals-energy complex in the light of South African economic historiography.' Transformation: Critical Perspectives on Southern Africa 71, pp. 3-25.

Geels, F. (2002) 'Technological transitions as evolutionary reconfiguration processes: A multi-level perspective and case study', Research Policy, 31(8/9), pp. 1257-1274.

Geels, F. W. (2005) Technological Transitions and System Innovations: A Co-Evolutionary and Socio-Technical Analysis Cheltenham: Edward Elgar.

Geels, F. W. (2011). 'The multi-level perspective on sustainability transitions: Responses to seven criticisms.' Environmental Innovation and Societal Transitions 1(1), pp. 24-40.

Geels, F. W. and J. Schot (2007) 'Typology of sociotechnical transition pathways'. Research Policy 36(3), pp. 399-417.

Goldthau, A. \& Sovacool, B. K. (2012) 'The uniqueness of the energy security, justice, and governance problem', Energy Policy, 41, pp. 232-240

Greyling, L (2010). The role of Parliament in energy oversight, Lance Greyling, MP, Independent Democrats, in Baker, L (eds) (2011). Sustainable energy solutions for South Africa: Ensuring public participation and improved accountability in policy processes, Conference report of the South African Civil Society Energy Caucus in Cape Town on 14 and 15 September 2010 Institute for Security Studies, Pretoria, South Africa 
Holloway, J. and S. Picciotto (eds) (1978) State and Capital: A Marxist Debate London: Edward Arnold.

ITUC (2011) Presentation by the 'International Trade Union Confederation' at the Climate Change workshop with South African trade unions - 27-28 July 2011 - Durban, South Africa,

Kern, F. (2011) 'Ideas, institutions and interests: Explaining policy divergence in fostering 'systems innovations' towards sustainability', Environment and Planning C: Government and Policy 29(6), pp $1116-1134$.

Kern, F. and A. Smith (2008) 'Restructuring energy systems for sustainability? Energy transition policy in the Netherlands', Energy Policy 36, pp. 4093-4103

Lawhon, M. And Murphy, J.T (2011) 'Socio-technical regimes and sustainability transitions: Insights from political ecology', Progress in Human Geography, published online 8 December 2011

Lehtonen, M. and F. Kern (2009) 'Deliberative Socio-Technical Transitions', in Scrase, I. and G. MacKerron (eds) Energy for the Future: A New Agenda. Basingstoke: Palgrave, 103-121.

Lund, $T$ (2011). 'Power mad - Government's tilt at an energy plan', Leader, 4 April [http://www.leader.co.za/article.aspx?s=2\&f=1\&a=2700]

Makgetla, N. and Seidman, A. (1980) Outposts of Monopoly Capitalism. Westport, Zed Press

McDaid L., Austin, B. and Bragg, C. (eds) (2010) 'Power to the people: raising the voice of civil society in electricity planning- Integrated Resources Plan 2010 inputs and departmental responses', WWF, South African Faith Communities Environment Institute, Institute for Security Studies, Cape Town, October 2010

McDonald, D. (2009) 'Electric capitalism: Conceptualising electricity and capital accumulation in (South) Africa', in: D. McDonald (eds) Electric Capitalism: Recolonising Africa on the Power Grid. Cape Town, HSRC Press 
Meadowcroft, J. (2005) 'Environmental political economy, technological transitions and the state', New Political Economy, 10(4), pp. 479-498.

Meadowcroft, J. (2009) 'What about the politics? Sustainable development, transition management, and long term energy transitions', Policy Sciences, 42, pp. 323-340

Meadowcroft, J. (2011) 'Engaging with the politics of sustainability transitions', Environmental Innovation and Societal Transitions, 1, 70-75

Mendonça, M., Jacobs, D. \& Sovacool, B. (2010) Powering the Green Economy: The Feed-in Tariff Handbook, Earthscan, London

Nakhooda, S. (2011) 'Empowering a Sustainability Transition? Electricity Planning in a Carbon Constrained South Africa', London School of Economics and Political Science, MSc thesis.

National Planning Commission (2013) 'Mineral resources'

http://www.npconline.co.za/pebble.asp?relid=163, accessed May $10^{\text {th }} 2013$

Newell, P. and D. Mulvaney (2013) 'The Political Economy of the Just Transition', The Geographical Journal, 179(2) June, pp. 132-140

Newell, P \& M. Paterson (1998) Climate for business: global warming, the State and capital. Review of International Political Economy 5(4), pp. 679-704.

Newell, P. and M. Paterson. (2010) Climate Capitalism: Global Warming and the Transformation of the Global Economy (Cambridge: Cambridge University Press).

Newell, P., N. Jenner, and L. Baker. (2009) Governing Clean Development: A Framework for Analysis. Development Policy Review 27 (6), pp. 717-739.

Pienaar, G., and Nakhooda, S., (2010). Keeping the Lights on? A Review of South Africa's Integrated Resource Plan for Electricity. Cape Town: Idasa. 
Perez, Carlota (2013) 'Unleashing a golden age after the financial collapse: Drawing lessons from history', Environmental Innovation and Societal Transitions 6, pp. 9-23.

Perez, C. (2002) Technological Revolutions and Financial Capital: The Dynamics of Bubbles and Golden Ages Cheltenham: Edward Elgar publishing.

Peters, D. (2010) Letter from the Minister of Energy to Ms. Samantha Bailey of 350.org South Africa, regarding the Integrated Resource Plan for Electricity, 2010, 21 June 2010

Prasad, G. (2008) 'Energy sector reform, energy transitions and the poor in Africa, Energy Policy, 36, 8, pp. 2806-2811.

Reddy, T. (2009) 'New energy to tackle climate change in South Africa?' Institute of Security Studies, 20 May 2009

Rip, A. \& Kemp, R. (1998) 'Technological change' in S. Rayner and E.L. Malone (eds). Human Choice and Climate Change 2, Oxford: OUP, pp. 327-399.

Republic of South Africa (RSA) (2006) No. 4 of 2006: Electricity Regulation Act, Government Gazette, Republic of South Africa, 5 July 2006

Salgado, I. (2010) 'Proposed renewable tariff cuts', Business report, 29 March

South African Renewables Initiative (SARi) (2010) 'Unlocking South Africa's Green Growth Potential', Update briefing, Department of Trade and Industry (DTI), Pretoria, December 2010 SAWEA (2011) Renewable energy in SA - going backwards or forwards? EE publishers panel discussion and debate, Midrand, 23 August

Scrase, I. and G. MacKerron (2009) (eds) Energy for the Future: A New Agenda Basingstoke: Palgrave.

Scrase, I. and A. Smith (2009) 'The non-politics of managing low carbon socio-technical transitions' Environmental Politics, 18(5), pp. 707-726. 
Shove, E. and G. Walker (2008) 'Transition Management and the Politics of Shape Shifting',

Environment and Planning A, 40, pp. 1012-1014.

Smith, A. Stirling, A. and F. Berkhout (2005) 'The governance of sustainable socio-technical transitions', Research Policy, 34, pp. 1491-1510.

Smith, A. \& Stirling, A. (2007) 'Moving Outside or Inside? Objectification and Reflexivity in the Governance of Socio-Technical Systems', Journal of Environmental Policy \& Planning, 9, pp. 351373

Steyn, G. (2006) Investment and uncertainty: historical experience with power sector investment in South Africa and its implications for current challenges, Working paper prepared for the Management Programme in Infrastructure Reform and Regulation at the Graduate School of Business at the University of Cape Town, 15 March 2006

Swilling, M. and E. Annecke (2012) Just Transitions: Explorations of Sustainability in an Unfair World. South Africa: UCT Press.

Tyler, E. and H. Winkler (2009) Economics of Climate Change: Context and Concepts related to Mitigation, unpublished report. Cape Town: Energy Research Centre.

Unruh, G. C. (2000). 'Understanding carbon lock-in'. Energy Policy 28(12), pp. 817-830

van der Pijl, K. (1998) Transnational Classes and International Relations. London: Routledge.Verbong, G. and D. Loorbach (eds) (2012) Governing the Energy Transition: Reality, Illusion or Necessity? New York: Routledge.

Wang, T. and J. Watson (2010) 'Scenario analysis of China's emissions pathways in the 21st century for low carbon transition.' Energy Policy 38(7), pp. 3537-3546.

Watson, J, Byrne, R. Ockwell, D. and Stua, M., Mallett, A. (2010). Low Carbon Technology Transfer: Lessons from India and China, Sussex Energy Group, Policy briefing, Number 9, November 
2010.Winkler, H. (2011) 'Will the IRP meet SA's carbon emission target?' Engineering News, 22 April

Winkler, H. and A. Marquard (2007). Energy development and climate change: decarbonising growth in South Africa. Human Development Report Office Occasional Paper 29. New York: UNDP.

Yelland, C (2010). "National integrated resource plan, a document to shape our future". Daily

Maverick, 23 April 2010. http://www.thedailymaverick.co.za/article/2010-04-23-national-integratedresource-plan-for-electricity-a-document-to-shape-our-future (accessed 12 February 2011)

Yelland C (2011).Renewable energy: a disquieting move from transparent to opaque. Daily Maverick. 31 August 2011. http://dailymaverick.co.za/article/2011-08-31-renewable-energy-a-disquieting-movefrom-transparent-to-opaque

Ziramba, E. (2009). 'Disaggregate energy consumption and industrial production in South Africa.' Energy Policy 37(6), pp. 2214-2220 


\section{Figure 1}

Increasing structuration

of activities in local practices

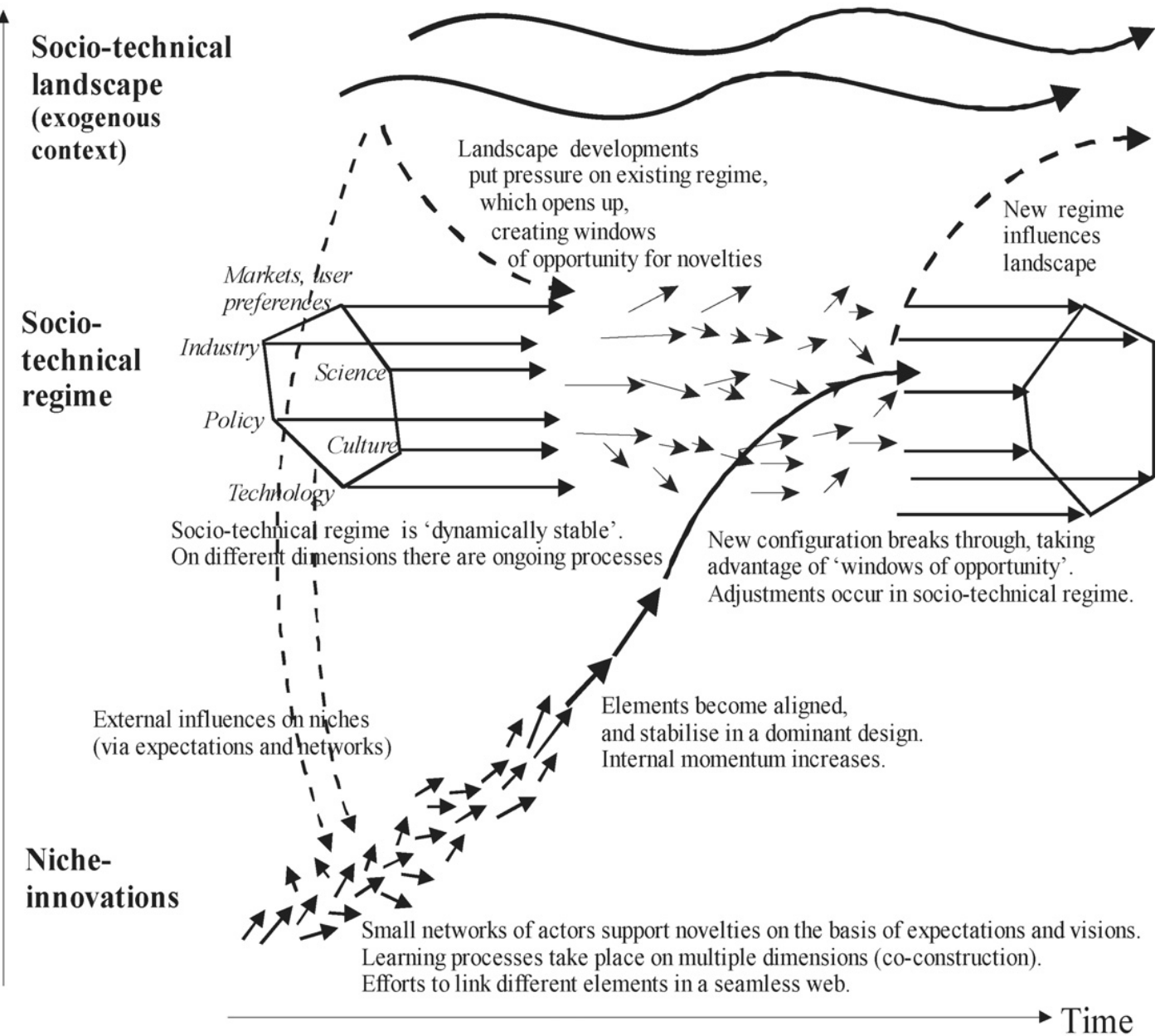

Source: Geels and Schot (2007:401, adapted from Geels (2002:1263) 
Figure 2

\section{Policy-adjusted IRP 2010: total envisaged}

capacity 2030

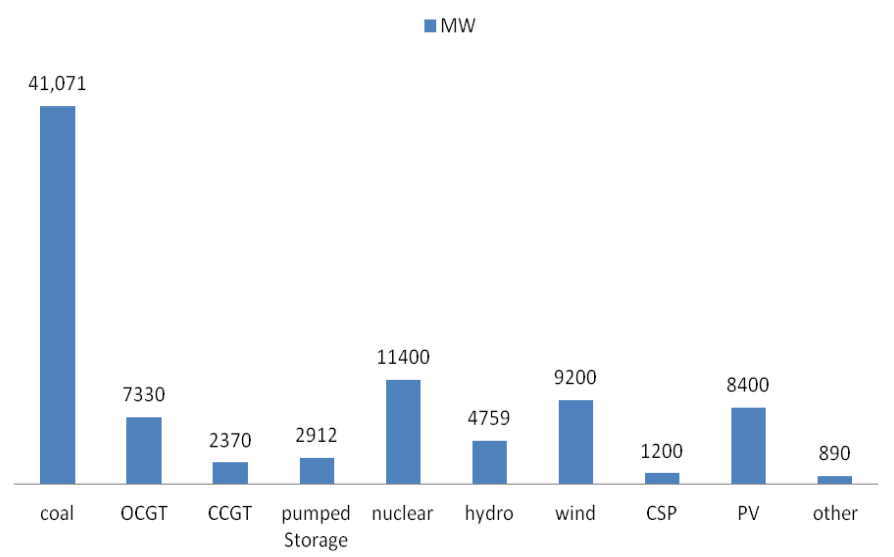

Source: (DoE 2011:14). Acronyms: OCGT (Open Cycle Gas turbine), CCGT (Combined Cycle Gas Turbine), CSP (Concentrated Solar Power), PV (Photovoltaic), MW (Megawatt). 
Table 1: the DoE technical task team

\begin{tabular}{|c|c|c|}
\hline NAME & SECTOR & INSTITUTION/ AFFILIATION \\
\hline Neliswe Magubane & Government & Director General, Department of Energy (DoE) \\
\hline Ompi Aphane & Government & DoE \\
\hline Ria Govender & Government & DoE \\
\hline Thabang Audat & Government & DoE \\
\hline Kannan Lakmeerharan & State Enterprise & Eskom Systems Operations and Planning \\
\hline Callie Fabricious & State Enterprise & Eskom planning and market development \\
\hline Mike Rousouw & Business - coal & Xstrata \\
\hline Ian Langridge & Business - coal & Anglo American \\
\hline Brian Day & $\begin{array}{l}\text { Business - coal/ } \\
\text { renewable energy }\end{array}$ & Exxaro (see chapter 4 ) \\
\hline Piet van Staden & $\begin{array}{l}\text { Business - fossil } \\
\text { fuels }\end{array}$ & SASOL \\
\hline Kevin Morgan & $\begin{array}{l}\text { Business - } \\
\text { smelters/coal }\end{array}$ & BHP Billiton \\
\hline Paul Vermeulen & $\begin{array}{l}\text { Local govt-owned } \\
\text { company }\end{array}$ & City Power (Johannesburg) \\
\hline Doug Kuni & Business & $\begin{array}{l}\text { South Africa Independent Power Producers } \\
\text { Association }\end{array}$ \\
\hline
\end{tabular}




\begin{tabular}{|l|l|l|}
\hline Roger Baxter & Business & Chamber of Mines \\
\hline Prof. Anton Eberhard & Academic & $\begin{array}{l}\text { Graduate School of Business, University of } \\
\text { Cape Town }\end{array}$ \\
\hline Shaun Nel & Business - project & $\begin{array}{l}\text { Gobodo systems (whom Eskom listed as a } \\
\text { client) }\end{array}$ \\
\hline
\end{tabular}

Source: McDaid et al. 2010

\footnotetext{
${ }^{1}$ We are grateful to the two anonymous reviewers of this paper for positive and useful feedback. We also gratefully acknowledge the support of the ESRC (066-27-0005) for the research undertaken for this paper.
} ${ }^{2}$ South Africa holds the world's largest reported reserves of gold, platinum group metals, chrome ore and manganese ore, and the second-largest reserves of zirconium, vanadium and titanium. In a report commissioned by US-based Citigroup bank, South Africa was ranked as the world's richest country in terms of its mineral reserves, worth an estimated \$2.5 trillion (National Planning Commission 2013).

${ }^{3}$ Notably the Department of Trade and Industry's Industrial Policy Action Plan 2011/12-2013/14 (IPAP), the Economic Development Department's New Growth Path (NGP), and the Department of Energy (DoE)'s Integrated Resource Plan (IRP) 2010.

4 'Financialisation' refers to "a self-absorbing process that does not necessarily return money into the real economy of production" (Freund 2010:21). It is a central feature of South Africa's MEC and as a 'landscape' trend since 1970s includes the proliferation of financial markets and institutions, the expanding range of financial services, increased international integration of national economies and the separation of industrial from finance capital as driven by trends of neo-liberal economic development. The result is that economic and social life is made vulnerable to financial instability (Fine 2008, 2009; Ashman et al 2011).

\footnotetext{
${ }^{5}$ Interview with manager, Sustainability, Eskom, May 2011

${ }^{6}$ Interview with head of South Africa's DNA, Department of Energy, May 2011.

${ }^{7}$ Interview with Designated Operational Entity (DOE) assessor, Johannesburg May 2011

${ }^{8}$ Interview with hydropower developer, May 2011.
} 


\footnotetext{
${ }^{9}$ Interview with BritishHigh Commission staff, May 2011.

${ }^{10}$ Interview with Project Coordinator, South African environmental NGO, May 2011

${ }^{11}$ Interview with head of South Africa's DNA, Department of Energy, May 2011.

${ }^{12}$ Interview with senior staff, Danish embassy, Pretoria May 2011.

${ }^{13}$ Interview with head of South Africa's DNA, Department of Energy, May 2011

${ }^{14}$ Interview with hydropower developer May 2011.

${ }^{15}$ Interviews with CDM office staff in the Department of Trade and Industry, May 2011.

${ }^{16}$ Interview with head of South Africa's DNA, Department of Energy, May 2011.

${ }^{17}$ Interview with state employee and former employee of Eskom, Johannesburg May 2011

${ }^{18}$ Interview with Programme Coordinator, British High Commission, May 2011.

${ }^{19}$ Interview with manager, Sustainability, Eskom, May 2011

${ }^{20}$ Involved in inter-business accords on energy efficiency, for example, as part of The Networked Leadership Partnership on Energy Efficiency as well as collaborations with government through the Energy Efficiency Technical Committee. Interview with Programme Coordinator, National Business Initiative, May 2011.

${ }^{21}$ Providing soft loans for the Solar Water Heater programme.

${ }^{22}$ Interview with manger, Sustainability, Eskom, May 2011

${ }^{23}$ The work by Burton (2011), Nakhooda (2011) and Baker (2012) might be considered exceptions in this regard
} 